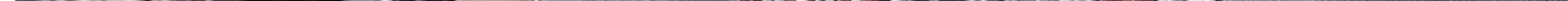




\title{
NARRATIVE CROSSROADS IN ECUADORIAN FIELDWORK
}

\section{Encrucijada narrativa en el trabajo de campo ecuatoriano}

\author{
iD Anne Carr, PhD. Faculty of Law, Universidad del Azuay. (Ecuador)
(acarr@uazuay.edu.ec) (https://orcid.org/0000-0001-5622-7085)
(iD Matías Abad-Merchán, Máster. Faculty of Law, Universidad del Azuay. (Ecuador)
(matabad@uazuay.edu.ec) (https://orcid.org/0000-0002-0248-2555)
iD Narcisa Ullauri. PhD. Faculty of Philosophy, Universidad del Azuay. (Ecuador)
(nullauri@uazuay.edu.ec) (https://orcid.org/0000-0001-7132-8335)
}

\section{Abstract}

The qualitative researcher is often described as a bricoleur who prepares a representation from multiple fragments of documentation yet, always involved in one way or another paying attention to situatedness and its neglected possibilities and temporalities in the web of everyday research life. At this narrative crossroads, fieldwork practices constitute ethnographic concepts composed of both separation and connection and are thus worlding tools that enable political thought and practice beyond the onto-epistemic limits of modern knowledge. Revisiting our fieldwork narratives from the paramo of the Southern Andes and the Pacific Coast of Ecuador offers the possibility to explore the neglected epistemic potential of the affective, ethical, and agencies of practical and material consequence from our thinking and action.

\section{Palabras clave}

Etnografía, trabajo de campo, ontología.

Keywords

Ethnography, field work, ontology.

\section{Resumen}

El investigador cualitativo se describe a menudo como un bricoleur que prepara una representación a partir de múltiples fragmentos de documentación, pero siempre involucrado de una forma u otra prestando atención a la situacionalidad y sus posibilidades y temporalidades desatendidas en la red de la vida cotidiana de la investigación. En esta encrucijada narrativa, las prácticas de trabajo de campo constituyen conceptos etnográficos compuestos tanto de separación como de conexión y, por lo tanto, son herramientas de mundo que permiten el pensamiento y la práctica política más allá de los límites onto-epistémicos del conocimiento moderno. Revisar nuestras narrativas de trabajo de campo desde el páramo de los Andes del sur y la Costa pacífico del Ecuador ofrece la posibilidad de explorar el potencial epistémico desatendido de las agencias afectivas, éticas y de consecuencia práctica y material de nuestro pensamiento y acción. 
1.

\section{Introduction}

The lens through which we see our own world and the world of others is made of the stories we hear. Our earliest received and exchanged texts are from the cradle, our first words, the sounds and senses of the immediate world. Our identities develop and form through narrative: 'the sort of identity to which a human being has access thanks to the mediation of the narrative function,' the narrative being a fusion of both historical and fictional (Ricoeur, 1991, p. 73). By positioning our 'selves' within the text alongside stories others tell and viewing those stories within the dominant discourses without privileging one story over another, we can create new and reflexive knowledge that can include the storyteller / researcher story.

It is often that the significance and contribution of particular happenings, actions, and events that link together retrospectively to form a narrative. Stories can be co-constructed by several speakers and that collaboration between the teller and the audience is intrinsic to narrative research. Participants and researchers ascribe meanings to events, but the stories are also told to other audiences, the readers, who will bring their own meanings. Stories are shared in many ways and have different functions in different communities. For example, in some communities, the teller expects the listener to supply the story's ending and this dialogical blurring of teller's and listener's roles means that as researchers we need to question our expectations when listening to stories.

Stories people tell - often painful stories - are constructed and located in the context from which they arise. They are not one story but a family's story, a community's story, a children's story. The recognition of the relationship between storyteller and listener, between knower and what is known during as well as after the fluid and changing experiences of contexts informs the process and outcomes of an inquiry confronting us as researchers and incites us toward a disposition to be attentive to practices that make worlds even if they do not satisfy the demand of modern epistemological proof. The story of the research process and the researcher's own engagement with that process becomes intrinsic and the fluctuating recursively reflects its boundless possibilities to create a bridge between listener and new knowledge that can both enable and prohibit translation and participation.

\section{2.}

\section{Literature Review}

Denzin and Lincoln's (2005) description of the qualitative researcher/listener, as a bricoleur who prepares a representation from multiple fragments, allows an approach to narrative documentation through active engagement while at the same time incorporating multiple sources of data and multiple ways of collecting, neither explaining nor deducing anything. From this perspective it is possible to be 'in the field' with broader generative questions' in mind such as Why is this story told? When is it told? Where is it told? What is the position of the storyteller and the listener? Has the narrative been told before? Is it political?

These are questions that allow linking observations while at the same time maintaining an open and unprejudiced mindset. This is the practice of arriving at a crossroads involving the practices of the researcher and of those that she/he works with. At this crossroads, fieldwork practices constitute ethnographic concepts composed of both the separation and the connections and are thus worlding tools that enable political thought and practice beyond the onto-epistemic limits of modern knowledge and what its practice allows (De la Cadena, 2018).

As such, ethnographic concepts lie within the field 
of political ontology which simultaneously stands for reworking an imaginary of politics, for a field of study and intervention, that del a Cadena describes as the power-charged terrain of entangled worldings and their dynamics, for a modality of analysis and critique that is permanently concerned with its own effects as a worlding practice. Engaging "more substantially and deeply in telling stories around experientially observed and researched terrains" (De la Cadena, 2018, p. 21) offers the possibility to explore the neglected epistemic potential of the "affective, ethical, and hands-on agencies of practical and material consequence" (p. 4) of our thinking.

\section{3.}

\section{Method}

In this paper, rather than contextualizing the time and place where the experiences occurred by reconstructing individual stories, facts, sequence of events and their results to identify categories and themes in the narrative data, we instantiate our ontological disconcertment about academic good (and bad) to point to even thicker possibilities to retell "involved stories, neither theoretical nor descriptive that are open to alternative readings, yet situated" (Bellecasa, 2017).

By paying attention to our situatedness in three narratives of Ecuadorian fieldwork - two in the Sierra and one from the Pacific Coast - we attempt to question the neglected possibilities and neglected temporalities in the "living mesh" (Bellacasa, 2017, p. 20) of our involvement in those narratives to ask different questions about the data.

\section{4.}

\section{Results}

\subsection{Narrative 1}

The purpose of our 'water filter' collaborative project "with" people rather than "on" or "about" people (Bhattacharya, 2008, p. 305) was to bring about positive practical change in the lives of communities in the Southern Andes and Ecuadorian Amazon region through the delivery of water filters in a collaboration between a university and international non-profit organization. This purpose constantly reminded us to reflect on how the intersecting differences of class, colour, institutional organization, locations, and gender were shaping our experiences in the field. Several encounters reminded us that the inequalities implied in the intersecting differences that make up our positionalities could not be eliminated, both in the field and in the documenting process (Nagar, 2014) but could be revisited, for example, certain failures in the participatory process that were both our own and also pertained to conventions of academic research more broadly.

One was falling into what D'Arcangelis (2018) calls 'the White settler fantasy of transcending colonialism' which arose when a community vigorously rejected receipt of water filters. Second, an encounter of differences when facing indigenous politics and cosmologies and third, discussion as a place of equality between adults and children where being conversational partners is by definition accepting each other as equal. It presupposes taking thoughts expressed by partners with seriousness; it presupposes listening to them. By this it does not only enable them to voice their opinions (they might, actually, have none), but also helps them to seek their own voice. Or, as Vansieleghem (2005) puts it: "After all, does not the community of inquiry always imply thinking with the other, facing conflict with the other, searching for an answer with the other, doubting with the other...?" (p. 33). In revisiting these narratives, we are concerned for representation and voice by paying attention to the major discursive strategy of stereotyping. Bhabba (1994) notes that

\footnotetext{
"the important feature of colonial discourse is the dependence on the concept of fixity in the ideological construction of otherness. Fixity, as the sign of cultural/historical/racial difference in the discourse of colonialism, is a paradoxical mode of representation: it connotes rigidity and an unchanging order as well as disorder, degeneracy and daemonic repetition... The stereotype....is the major discursive strategy". (p. 66)
}

Saraguro region, Loja Province, Southern Ecuador We had experienced an arduous 20 or so hours of traveling and delivering water filters to dispersed 
rural and indigenous communities through collaboration with local juntas. On arrival in each community, we had settled into a collaborative presentation format with community members about the set up and maintenance of water filters for sustainability that was translated from Spanish and English into Kichwa by members of the local junta.

As a team, we had discussed how, especially since two members of the project were female, older and whiter, that delivering filters could be perceived as colonial 'gifting' but we were still surprised to be "un-greeted" and told to leave with forceful words as the leader, an older woman. Standing behind her were several other community members all holding sticks and shovels. She told us they had no interest in the water filters and that we only wanted their vote and/or we would return and ask for money and that it was necessary to talk with more community members since only six were present at this meeting which took place on the mountainside.

People who may be marginalized and who live in povertydecidewhetherandhow toparticipateagainst the backdrop of complex histories of exclusion, discrimination, and violence. Their survival and access to income, services, or benefits often hinges on patronage relations which, if challenged, could cause them to lose what little they have and risk further exclusion. In this case they may have been reassessing the 'costs and consequences' of their choices (Kabeer 2001). Perhaps the community leader's response may have reflected cultural and ideological 'beliefs' about power and those who are seen to represent it.

Her response "turned into muscular patterns and bodily automatisms... a way of bearing one's body, presenting it to others, moving it, making space for it, which gives the body its social physiognomy' or 'bodily hexis'" (Bourdieu, 1980, p. 474). The body thus works as a 'memory-jogger' with its "complexes of gestures, postures and words... which have only to be slipped into, like a theatrical costume, to awaken, by the evocative power of bodily mimesis, a universe of ready-made feelings and experiences" (ibid.).

If power is embodied, what does this mean if large parts of our speech and behaviour are derived from our experiential and habituated "logic of practice" (Bourdieu, 1980) Can we use our senses and bodies more intentionally to unlearn and transform our interactions in the situations with which we engage?

Is 'doing development' -distributing water filters - a manifestation of neo-imperialism? Is it as Cammarota (2011) states, a phenomenon in which a white person "guides people of color from the margins to the mainstream with his or her own initiative and benevolence" tending to render people of color "incapable of helping themselves" disposing them of historical agency (p. 343)?

For Althusser (2014), the link between development and altruism is inherently connected to the prevailing ideological state apparatus of the Global North - capitalism. The 'white saviour' is positioned within their imaginary relations of production, i.e., as a privileged individual from the Global North, whereas the altruistic self then acts according to the ideological interpellation that has birthed the heroes and heroines in popular culture through the influence of collective cultural romanticization. In other words, every individual has a consciousness and chooses ideas, but they are forced to act the practices and rituals of ideological state apparatuses upon their ideas in order not to seem inconsistent, cynical or perverse.

While the 'enlightened altruistic saviour' seeks to promote progress and development in the Global South, according to Fanon (1970), the person of colour is victimised, de-rationalised and contrasted to the heroism of the 'white saviour'. "The black soul is the white man's artefact: the creation of blackness in the white imagination" (Fanon, 1970, p. 45). This quote illustrates the constructed master/ slave relation within the ruling ideology that Fanon outlines, so that the black man is merely a tool for the recognition of white subjectivity.

Our translator thanks the leader and gestures to us it is time to leave saying we can leave the filters with him since he will return and talk again when the community invites him. Is this a way that we can listen to the agency of local actors - an interpellation into the underlying power discourse of development and philanthropy ideologies? 
Jin \& Cortazzi (2002) states "stories are dynamic, changeable, never the same. Yet they convey something about what we believe to be stable in the world. They say something about us as individuals, cultural creatures, historical beings. They shape our actions and are at the same time what is left when the action is gone" for the teller and the listener (p. 49).

\subsection{Narrative 2}

The páramos (high plateaus of Ecuador), where we documented both Narratives 1 \& 2, found in 18 of 24 provinces and covering 1.33 million hectares (roughly $5 \%$ of its total area) are an important ecosystem which is a crucial source of water for local communities and cities. Situated between 3,200 and 4,200 metres above sea level, these high plains grasslands function like a sponge, absorbing and storing large volumes of freshwater that is then released continuously and gradually, feeding river systems and preventing abrupt variations in their flow.

However, with a projected reduction in annual precipitation, some páramos are disappearing and vital water resources are being absorbed by the highly permeable volcanic soils beneath them, transforming these areas into highly fragile deserts like the dry páramos of the central province of Chimborazo. Climate change affects all of the páramo, which is an integral part of daily life through the supply of water that affects the entire ecosystem. The páramo exists above the $3000 \mathrm{~m}$ cloud forest. Some cattle are raised despite a climate with low temperatures which drop below freezing on still, clear nights, especially in frost pockets, as well as high winds, rain, and drizzle.

The community of 40 families to whom we are delivering water filters has gathered to hold a minga or community work time to clear the mountainside of invasive pine trees that inhibit the growth of indigenous plants.

Samuel and I stand on the páramo -mountain highland above the treeline- altitude 4,200 located within a canton (small territorial district) consisting of thousands of hectares of arable and forest land. There is a vista of twenty of more kilometres. An indigenous Saraguro community, the 40 families live in a dispersed sprinkle of small adobe houses that dot the landscape inhabited by many cows. "Their houses are so dispersed. How do they access water? Is it a stream or rain? Where is the water?" I ask in Spanish, my second language like his.

Samuel is a member of the local junta (usually a group of three elected officials), his first language is Kichwa. He wears traditional short pants to below the knee in a climate where the ground stays very cold, but your face can burn from the sun's intensity. He wears a very stylish leather jacket. His braided hair is waist length. He wears a round topped hat. He responds, "They are here to look after the land." (field notes October 2019). He says nothing more as he continues to look across the valley.

Here 'development' - fixing the noted problem - is no longer the organizing principle of social life in an ecologically wise and socially just world. "It is in fact one of my central intuitions that modern knowledge is essentially a trap to itself, such that most forms of 'explanation' are guest unaware they are actually being hosted - predators who do not know their own condition as prey" (Corsín Jiménez, 2018).

This proposition of the "trap" as a concept and ethnographic tool to search the relations that compose and perform knowledge works as a machine: a gathering of heterogeneously composed relations and conditions required to capture prey that therefore is also of the predator's design. In this sense, the trap works as an interface, proposing that, just as prey and predator are trapped to (and with) each other, the subject and the object of modern knowledge cannot be conceptually (or practically) separated from one another recursively making a concept full of relations-trap-to think about concepts (and the relations that make them). However, subject to creative originality, the architecture of a trap conditions what it catches, but the catch can also surprise the trap maker signalling the importance of the material composition of knowledge.

In indigenous cosmologies, land is shorthand for land, water, air, plant and animal life, and people. David Herman proposes, (2004) "storytellers use 
deictic points and other gestures to map abstract, geometrically describable spaces onto lived, humanly experienced places" (p. 27). The subjective component of space turns it into an infinite series of authorships - or so it seems - wherein speaking subjects both define it and are defined by it. Still, the relationship between space and place, and between topography and place, remains a problematic encounter that both exceeds the map and remains representable by it. Caring for the land is more binding than just being concerned; it requires active maintenance or improvement, just as caring for someone is more binding than just being concerned highlighting the importance of a speculative, openended, non-predetermined mode of thinking to counteract universal claims about what care, i.e., assuring the availability and sustainability of clean drinking water, should look like.

\subsection{Narrative 3}

The earliest recording of an earthquake in Ecuador was on 4 February 1797 at 12.30 pm. At 8.3 magnitude it activated the Cotopaxi volcano leading to lava raining down onto the town of Riobamba and an estimated 40,000 lost their lives. Ecuador at the geolocation of latitude -1.160171 and longitude -78.432915 has always been affected by frequent earthquakes that result from movement on the subduction interface along the plate boundary, those that result from deformation within the South American and Nazca Plates and those that are associated with active volcanoes. For example, as of 8 April 2019, there had been one earthquake in the previous 24 hours, two earthquakes in the past 7 days, eleven earthquakes in the past 30 days and 56 earthquakes in the past 365 days. (Earthquakes in Ecuador, n.d.)

In December 2018 children aged 9-11 years, from the small coastal community of Canoa, recount to researchers - teachers and adult students the everydayness of being prepared for the next earthquake. Their shared narratives told in their head teacher's room (the only room in the school with electricity) contain distressing descriptions of their previous disaster experiences 18 months earlier in Canoa, April 2016: evacuation decisions, risk of separation from parents, witnessing injury and death of family members and peers in the 7.8 earthquake that took the lives of 63 members of their community and 675 in the general area. Their classrooms, six wooden huts with bamboo roofs surround a large open area of sand. Their school is less than 100 feet from the ocean.

The children sit around an adult desk. They have felt pens and personal sheets of paper about $10 \mathrm{~cm}$ square.

Can you tell us about the earthquake? Asks an adult student.

C1: Natural disasters are very violent because even if it is a small earthquake, old people who have heart problems could get scared and get a heart attack and die. The same thing if there is a tsunami, the sea comes to us and because we do not have much time to run, it can cause more damages than an earthquake.

C2: Sometimes, they (earthquakes) are very violent and they can be landslides or tsunamis. It's because of the tectonic plates or also because of the pollution and global warming.

C3: They are very violent movements that affect us and the society. Our houses fall down.

C1: We have to help our friends, see if there is someone who has been hit and see if there are friends in the classrooms or bathrooms that have been hit and take them out so they do not get hit again.

C4: My family says that it is good that in the case that an earthquake happens I have to apply the security measures I learn at school and not do things like I don't want to get out because that is going to fall on me or run. They tell me to be calm because only God knows when our lives are going to end. When it is our time, it is our time and when it is not, even if three slabs fall on them, they won't die.

Strictly speaking, conversations do not end when we stop talking; they can go on for years after partners engaged in a conversation; and sometimes 
they only really begin when we stop speaking and start thinking while going our own ways. They can live in our memories as constant inspiration, or sometimes as a bitter reminder. It is likely that parents and grandparents, who generationally may not have been exposed to risk information in school themselves, and who may not want to scare their children about another disaster that may or may not occur, however, they reinforced what the children had learned at school.

C5: The dangerous places at school are the kitchen, the roof, the bathrooms. At home, it's light posts, loose walls. We must go to a place where there are no things that could fall on us or hurt us.

C6: First we form a circle then there is a door here at the back and we go through and some people go to verify if there is someone or a kid inside and others put a bandage on them. We have to form a snail in the middle of the court which makes us calm down. We must take the emergency backpacks and because we are in the last year of school we have to take care of the younger children, be with them to help them. If we are at home we have to run to the hill the one that has the antenna.

C7: We must help the ones that need the most like ill or disabled people. We have to calm down because some of our relatives may not be good and they can get scared if we scream and push each other.

When we listen to a child or children in a welcoming context, what they say may surprise us. Moreover, what they say may help to eliminate predetermined meanings and totalizing practices that may have excluded, marginalized, ignored them; what they say is no longer seen as something simply cute or funny. It is not a case of inverting the traditional hierarchy replacing the adult with the child; nor should the adult just be a passive listener. Rather, the challenge is creating the context in which children's theories, research and skills are legitimized and listened to, of working in a group consisting of both adults and children to develop meaningful practices in a community to learn.
This idea of "Listening to a child" may appear too vague. The challenge is precisely how one should listen to children, and in what circumstance? We offer it to children because they have the right for it; because they can be heard through it. One of the main advantages of a dialogue is that one can, as Socrates said, "examine" oneself through it, and by that also share herself of himself with others while also simultaneously listening to them (Rinaldi 2001).

In fact, if philosophy is understood as nothing else but a continuous conversation about ourselves (as perhaps Richard Rorty would see it), then children, as well as adults and everybody else, should at least have a right to decide whether to participate in it or not. We should start listening to individual children without expecting anything in return. This is also what the article 12 of the Convention on the Rights of the Child obliges us to do.

Bruner (2003) describes the ways of telling and the ways of conceptualizing that go with them become so habitual that they finally become recipes for structuring experience itself, for laying down routes into memory, for not only guiding the life narrative up to the present but directing it into the future" (p. 114). On the contrary to the implication that narratives are static entities, they depend on the situation, moment and place meaning that it is necessary to pay careful attention to context

C9: Yesterday (referring to 6.0 tremor December 3, 2017 the day prior to the focus group interviews) I got so scared because it happened when I was sleeping and I could not get out of bed. I woke up because of the earthquake and tried to run outside but the door was locked. While I was looking for the keys, it finished and then I went out and people were yelling, 'where are my children.'

C10: Yes ... I was sleeping and my grandmother started to pray and my aunt and sister started to scream. I was telling them not to scream because an earthquake is something normal and all of that.

C14: At that moment, my little sister and I went under a table and I covered my sister so she 
won't get scared. My older sister was at the door and the door fell on my mom. But I was the last one to get out because the door hit me on my arm and hurt so much ... my sister had to bandage my arm it was really bloated. When I went outside with my sisters, a wall fell on my older sister and hit her head. My cousin, Angelica was high up in the next building. It has like four or five floors and she died there. She was three years old and that hurt my heart very much. I saw where she was lying and how the building fell down on her.

C15: We helped one of my mom's friends. She had a 5-year-old girl and the girl had been hit. All the hotels were down. There was also a 10-year-old girl we helped and then we saw that the 5-year-old girl was dead and we went to see my mom's siblings so we calmed down.

We know on this particular occasion why these stories are told, when they are told and where. What we are curious about is the position of each storyteller and if the narrative has been told before, to whom, where and when in a similar way. As Squire (2008) puts it: "[s]tories operate within 'interpretive communities' of speakers and hearers that are political as well as cultural actors. They build collective identities than can lead, albeit slowly and discontinuously, to cultural shifts and political change" (p. 55).

Knowledges are world-making practices, they tend to make the worlds they know. In other words, knowledge is recursive: knowledge reveals itself by making its objects (conceptual or material) through procedures that need to be recognizable (as knowledge) by the community that practices it. What the community of knowers does not recognize as knowledge is displaced along with its reality-making possibilities. Thus, the practice of dialogue is, on the one hand, the best way to give someone her voice and enable her to recognize it, and on the other hand, the practice including reflective and exegetical practice allows people - adults and children - to be informed about a wider variety of communication possibilities. A practice of open conversation tries to provide reasons for one's ideas to examine oneself and one's understanding through a dialogue with another person.
Vansieleghem (2005) quotes Hannah Arendt's insight that "Thinking arises as the response to the encounter that is not to be anticipated or predicted or even perhaps believed" (p. 28) that suggests dialogue is formulated in such a way that people - in this case children - have a right to participate in a discussion, and a right to voice their opinion and be heard. Talking with them implies thinking with the other, facing conflict with the other, searching for an answer with the other, doubting with the other..." (p. 33).

\section{5.}

\section{Conclusions}

Thinking with care as we position our 'selves' within the text alongside stories others tell and viewing those stories within the dominant discourses is about not ignoring the involvement and obligation to the specificity of moments, particular relations, of ecologies where the ethical is at the same time a personal agency and embedded in the 'ethos' of a community" (Bellacasa, 2017 p. 151) without "defining in advance a code of conduct or a normative definition of right and wrong" (p. 152). Engaging "more substantially and deeply in telling stories around experientially observed and researched terrains" (p. 21) can then not 'merely' make "(...) the complexities of thinking with care even more intricate" (p. 21). It offers also the possibility to explore the neglected epistemic potential of the "affective, ethical, and hands-on agencies of practical and material consequence" (p. 4) of our thinking.

Political ontology operates on the presumption of divergent worldings constantly coming about through negotiations, enmeshments, crossings, and interruptions. It asks how those practices transpire and with what consequences thus simultaneously standing for reworking an imaginary of politics (De la Cadena \& Blaser, 2018). Without privileging one story over another, in this modality of analysis and critique that is permanently concerned with its own effects as a worlding practice, we can create new and reflexive knowledge that can include the storyteller / researcher's story. 
Perhaps listening to ourselves with care offers a possibility to avoid "[t]he fatal flaw in (...) standard analytics of conceptualizing the scholar "as removed observer" (Verran, 2017, p. 20) and rather think and live a two-wayness of concepts not only between the knower and her/his mind but also between the knower and the perspectives of the ecologies that the knowing emerges from. In this way, perhaps we can attend to generating the neglected possibilities and obligations of being academics.

\section{6.}

\section{References}

Althusser, L. (2014). On the reproduction of capitalism: Ideology and ideological state apparatuses. Verso Trade.

Andrews, M., Squire, C., \& Tamboukou, M. (Eds.). (2013). Doing narrative research. Sage.

Bhattacharya, H. (2008). New critical collaborative ethnography. Handbook of emergent methods, 303-322.

Bellacasa, M. P. De la (2017). Matters of care: Speculative ethics in more than human worlds (Vol. 41). U of Minnesota Press.

Bhabha, H. K. (1994). The Location of Culture London: Routledge.

Boltan, L., Lattas, A., Redmond, A., Rumsey, A., Rose, D. B., Silverman, E. K., ... \& Wassmann, J. (2012). Emplaced Myth: Space, Narrative, and Knowledge in Aboriginal Australia and Papua New Guinea.

Bourdieu, P. (1980). 1990. The logic of practice. Trans. Richard Nice. Stanford, Calif.: Stanford University Press.

Bruner, J. S. (1990). Acts of meaning (Vol. 3). Harvard university press.

Burr, J. (2010). The Altruistic Self and the Desire of Developing Others: Towards a Post-development Ethos of Action (Doctoral dissertation, Dalhousie University).
Cammarota, J. (2011). Blindsided by the avatar: White saviors and allies out of Hollywood and in education. Review of Education, Pedagogy, and Cultural Studies, 33(3), 242-259. https://doi.org/10.1080/10714413.2011.585287

Corsín Jiménez, A. (2018). Spider web anthropologies: Ecologies, infrastructures, entanglements.

D'Arcangelis, C. L. (2018). Revelations of a white settler woman scholar-activist: The fraught promise of self-reflexivity. Cultural Studies $\leftrightarrow$ Critical Methodologies, 18(5), 339-353.

https://doi.org/10.1177/1532708617750675

De la Cadena, M., \& Blaser, M. (Eds.). (2018). A world of many worlds. Duke University Press.

Denzin., N. \& Lincoln, Y. (2005). The Sage handbook of qualitative research. Sage.

Earthquakes in Ecuador. (n.d.). Earthquakes.zone. Retrieved November 11, 2020, from https://earthquakes.zone/ecuador

Fanon, F. (1970). Black skin, white masks (pp. 1330). London: Paladin.

Herman, D. (2004, April). Points, spaces, and places: The functions of gesture in everyday storytelling. In Meeting of the Society for the Study of Narrative Literature. University of Vermont, Burlington (pp. 22-25).

Hudis, P. (2015). Frantz Fanon: Philosopher of the barricades. Pluto Press.

Jin, L., \& Cortazzi, M. (2002). Cultures of learning, the social construction of educational identities. University Press of America, Inc.

Kabeer, N. (2001). Reflections on the measurement of women's empowerment.

Nagar, R. (2014). Muddying the waters: Coauthoring feminisms across scholarship and activism. University of Illinois Press. 
Ricoeur, P. (1991). Narrative identity. Philosophy today, 35(1), 73-81.

https://doi.org/10.5840/philtoday199135136

Rinaldi, C. (2001). The pedagogy of listening. The Listening Perspective from Reggio Emilia.

Spillers, H. J. (2004). Topographical topics: Faulknerian space. The Mississippi Quarterly, 57(4), 535-568.

Verran, H. (2017). Matters of Fact(ization), Matters of Capitalization, and Matters of Care, EASST, 36(1), 19-20. https://bit.ly/3eU2bRN

Vansieleghem, N. (2005). Philosophy for Children as the Wind of Thinking. Journal of Philosophy of Education, 39(1), 19-35.

https://doi.org/10.1111/

j.0309-8249.2005.t01-1-00417.x 
Universidad Verdad, n 77. 2020 / Revista Científica de Ciencias Sociales y Humanas Julio - Diciembre 2020 / ISSN impreso: 1390-2849 ISSN online: 2600-5786. 